\title{
Human microbiome as a source of folate modifiable by nutritional and non-nutritional factors*
}

\author{
Mikrobiom człowieka jako źródło folianów modyfikowalne pod wpływem czynników \\ żywieniowych i pozażywieniowych*
}

\author{
Dorota Gumiela ${ }^{凶}$
}

Uniwersytet Medyczny im. Karola Marcinkowskiego w Poznaniu, Katedra i Zakład Biochemii i Biologii Molekularnej, ul. Święcickiego 6, 60-101 Poznań Poznan University of Medical Sciences, Chair and Department of Biochemistry and Molecular Biology

$\triangle$ dgumiela@ump.edu.pl

\begin{abstract}
Hippocrates, in 400 years before our era, indicated that the intestines are central to human health and that "bad digestion is the root of all evil". The microbiome influences immune status, protects against colonization by pathogenic microorganisms, performs metabolic and trophic functions, and participates in the synthesis of vitamin $\mathrm{K}, \mathrm{B}_{1}, \mathrm{~B}_{6}, \mathrm{~B}_{12}$, and folic acid. Diet is a key factor in determining its composition. For many microbial strains, p-aminobenzoic acid is an indispensable substrate for the formation of folates. Bifidobacteria (HRB) strains in humans are mainly responsible for the synthesis of folates. Non-HRB strains that have the ability to synthesize folates include $B$. thermophilum and B. longum ssp. The only hitherto indicated factor
\end{abstract}

that can affect the microbiota's potential for folate synthesis is metformin, which improves glucose tolerance in people with type II diabetes. Metformin reduces the production of glucose in the liver by inhibiting gluconeogenesis and glycogenolysis, increases the sensitivity of tissues to insulin, and reduces the absorption of glucose. In order to thoroughly understand the ability of the microbiota to synthesize folic acid, it is necessary to conduct studies that include people with varying degrees of exposure to factors that may affect health, such as: poor dietary habits, smoking, low physical activity, diet-related diseases, or taking medications.

Keywords: microbiome; diet; folates; metformin.

\begin{abstract}
ABSTRAKT
Hipokrates 400 lat p.n.e. wskazywał, że jelita są istotne dla zdrowia człowieka, a „złe trawienie jest korzeniem wszelkiego zła”. Mikrobiom wpływa na stan immunologiczny, chroni przed kolonizacją mikroorganizmami patogennymi, spełnia funkcje metaboliczne i troficzne, bierze udział w syntezie witaminy $\mathrm{K}$, $\mathrm{B}_{1}, \mathrm{~B}_{6}, \mathrm{~B}_{12}$ oraz kwasu foliowego. Dieta jest kluczowym czynnikiem determinującym jego skład. Dla wielu szczepów mikrobiomu kwas p-aminobenzoesowy jest niezbędnym substratem do wytworzenia folianów. Szczepy ludzkich Bifidobacterii (HRB) odpowiadają głównie za syntezę folianów. Do szczepów nie-HRB, które posiadają zdolność syntezy folianów, należą $B$. thermophilum i $B$. longum ssp. Jedynym dotąd wskazywanym czynnikiem, który może wpływać na potencjał mikrobioty do syntezy
\end{abstract}

folianów, jest poprawiająca tolerancję glukozy u osób z cukrzycą typu II metformina. Zmniejsza ona wytwarzanie glukozy $\mathrm{w}$ wątrobie $\mathrm{w}$ wyniku hamowania glukoneogenezy i glikogenolizy, zwiększa wrażliwość tkanek na insulinę i zmniejsza wchłanianie glukozy. W celu dokładnego poznania zdolności mikrobioty do syntezy kwasu foliowego potrzebne jest przeprowadzenie badań, w których zostaną uwzględnione osoby w różnym stopniu narażenia na występowanie czynników mogących wpływać na stan zdrowia, takich jak: nieprawidłowy sposób żywienia, palenie papierosów, niska aktywność fizyczna, występowanie chorób o podłożu dietozależnym oraz przyjmowanie leków. Słowa kluczowe: mikrobiom; dieta; foliany; sposób żywienia; metformina.

\section{INTRODUCTION}

The human body is a habitat for bacteria, archaea, viruses, and unicellular eukaryotes that form a complex ecosystem in the genitourinary tract, alimentary tract, and respiratory tract [1].

\section{WSTĘP}

Ludzkie ciało jest siedliskiem bakterii, archeonów, wirusów i jednokomórkowych eukariotów, które tworzą złożony ekosystem głównie w układzie moczowo-płciowym, przewodzie

\footnotetext{
*An article based on Dorota Gumiela's master thesis entitled "Manner of Nutrition and the potential of the human microbiota to synthesize folates" defended at the Faculty of Food and Nutrition Sciences at the University of Life Sciences in Poznań. Promoter: dr inż. Anna Malinowska. The original contains: 80 pages, 15 tables, 1 figure and 148 references. * Artykułna podstawie pracy magisterskiej Doroty Gumieli pt. „Sposób żywienia człowieka a potencjał mikrobioty człowieka do syntezy folianów” obronionej na Wydziale Nauk o Żywności i Żywieniu Uniwersytetu Przyrodniczego w Poznaniu. Promotor: dr inż. Anna Malinowska. Oryginał zawiera: 80 stron, 15 tabel, 1 rycina i 148 pozycji piśmiennictwa.
} 
The number of microorganisms in the body exceeds 10 times the number of somatic cells [2]. The most intensely colonized and diverse environment is the human intestines, which due to their surface area $\left(200 \mathrm{~m}^{2}\right)$ and access to nutrients are an ideal place for microorganismal development. Diversity and density of bacterial species is dependent on many factors: age of the host, diet, lifestyle, and medication [1]. The diet is a particularly important factor in determining its composition. Hippocrates, in 400 years before our era, indicated that intestines are central to human health, and that "bad digestion is the root of all evil". Intestinal microbes influence, among others, immune status [2], protection against colonization by pathogenic microorganisms, and metabolic and trophic functions [3], as well as taking part in the synthesis of vitamin $\mathrm{K}, \mathrm{B}_{1}, \mathrm{~B}_{6}, \mathrm{~B}_{12}$ and folic acid [4]. The influence of the microbiota on human health has long been a subject of interest for many researchers. The large intestine [3] became a subject of particular interest, as did the search for the relationship between diet and the quantitative and qualitative composition of the microbiome [5]. Researchers are still trying to answer the question whether the microbiome can be an additional source of nutrients, including folates (vitamin $B_{9}$ ) [6, 7], and to what extent this endogenous source can affect their concentration in blood [8].

\section{FUNCTIONS OF THE MICROBIOTA}

The human microbiome consists of all the heterotrophic microorganisms that inhabit the human body. The microorganisms are not randomly dispersed in the body, but are located in strictly defines places, i.e. the upper respiratory tract, gastrointestinal tract, skin, reproductive system [9, 10]. In the human digestive tract, there are $10^{14}$ different types of microbial cells per 1 gram of intestinal contents, which comprise 17 families, 45 genera [11], and 2000 species [12]. The density of bacteria in the gastrointestinal tract increases as food moves through from the stomach $[11,13]$. In the human digestive tract, there is a large number of beneficial (eubiotic) microorganisms that exist in symbiosis with the host. These include Bifidobacterium and Lactobacillus $[14,15]$. Eubiotic microorganisms are responsible for the fermentation of saccharides and acidification of the intestinal environment. Due to the fact that they closely adhere to the intestinal wall, they ensure the balance of the ecosystem and prevent colonization by potentially pathogenic bacterial flora [14, 16]. Bacteria of the Bacteroides, Eubacterium, Clostridium, Staphylococcus, Pseudomonas, and Enterobacteriaceae type are in turn classified as opportunistic or potentially pathogenic microorganisms [15]. They may exhibit proteolytic activity, degrading protein and alkalizing the gastrointestinal tract by producing toxic substances. When the organism is in an equilibrium state, they do not show pathogenic activity $[14,16]$. The microbiota performs protective functions (it creates a protective barrier against pathogenic microorganisms), synthesizes vitamins K and B pokarmowym i drogach oddechowych [1]. Liczba drobnoustrojów w organizmie 10-krotnie przewyższa liczbę komórek somatycznych [2]. Środowiskiem najbardziej skolonizowanym i zróżnicowanym pod względem drobnoustrojów są ludzkie jelita, które przez swoją powierzchnię $\left(200 \mathrm{~m}^{2}\right)$ oraz dostęp do składników odżywczych są idealnym miejscem do ich rozwoju. Heterogeniczność i zagęszczenie gatunków bakterii jest uzależnione od wielu czynników: wieku gospodarza, diety, stylu życia i zażywanych leków [1]. Sposób odżywiania jest kluczowym czynnikiem determinującym skład mikrobioty. Hipokrates 400 lat p.n.e. twierdził, że jelita są istotne dla zdrowia człowieka, a „złe trawienie jest korzeniem wszelkiego zła”. Drobnoustroje wpływają m.in. na stan immunologiczny [2], chronią przed kolonizacją mikroorganizmami patogennymi, spełniają funkcje metaboliczne i troficzne [3], biorą również udział w syntezie witaminy $\mathrm{K}, \mathrm{B}_{1}, \mathrm{~B}_{6}, \mathrm{~B}_{12}$ oraz kwasu foliowego [4]. Wpływ mikrobioty na zdrowie człowieka stał się przedmiotem zainteresowania wielu badaczy, którzy szczególną uwagę poświęcają jelitu grubemu [3] oraz poszukiwaniu zależności pomiędzy sposobem żywienia a ilościowym i jakościowym składem mikrobiomu [5]. Naukowcy próbują odpowiedzieć na pytania, czy i w jakim stopniu może on stanowić dodatkowe źródło składników odżywczych (np. folianów) [6, 7] oraz w jakim stopniu to endogenne źródło witaminy $B_{9}$ może wpływać na ich stężenie we krwi [8].

\section{FUNIKCJE MIKROBIOTY}

Mikrobiom człowieka stanowią wszystkie drobnoustroje heterotrofityczne, które zasiedlają organizm ludzki. Nie jest on przypadkowo rozproszony w organizmie, ale zlokalizowany w ściśle określonych miejscach, tj.: górnych drogach oddechowych, przewodzie pokarmowym, skórze, układzie rozrodczym $[9,10]$.

W 1 g treści jelitowej występuje $10^{14}$ różnych komórek drobnoustrojów, w skład których wchodzi 17 rodzin, w tym 45 rodzajów [11] należących do 2 tys. gatunków [12]. Zagęszczenie bakterii w przewodzie pokarmowym wzrasta w miarę przesuwania się pokarmu od żołądka [11,13].

W przewodzie pokarmowym człowieka znajduje się duża ilość mikroorganizmów korzystnych (eubiotycznych), które pozostają w symbiozie z gospodarzem. Należą do nich pałeczki z rodziny Bifidobacterium i Lactobacillus [14, 15]. Mikroorganizmy eubiotyczne odpowiadają za fermentację sacharydów oraz zakwaszenie środowiska jelit. Dzięki temu, że ściśle przylegają do ściany, zapewniają równowagę ekosystemu i zapobiegają kolonizacji przez potencjalnie chorobotwórczą florę bakteryjną $[14,16]$. Bakterie z rodzaju Bacteroides, Eubacterium, Clostridium, Staphylococcus, Pseudomonas i z rodziny Enterobacteriacea zaliczane są z kolei do mikroorganizmów oportunistycznych, czyli potencjalnie szkodliwych [15]. Mogą one wykazywać działanie proteolityczne, rozkładając białko, i alkalizujące środowisko przewodu pokarmowego poprzez wytwarzanie substancji toksycznych. W stanie równowagi organizmu nie wykazują one 
and short chain fatty acids (SCFA), digests nutrients undigested by the human which generates energy from food, contributes to efficient intestinal motility, decomposes toxins and carcinogens, metabolizes drugs. Impairment of these functions may result in problems in maintaining homeostasis of the organism $[17,18,19]$.

\section{NUTRIENTS MODULATING THE COMPOSITION OF THE MICROBIOTA}

The development of the human microbiota is influenced by numerous factors including: gestational age, type of delivery, feeding and medications in the neonatal and infant period, diet at various stages of life, age, and medications [20, 21]. Analysis of the microbiome in relation to the host's characteristics may contribute to the understanding of all factors that influence the status of the microbiome and the reactions that contribute to the preservation of homeostasis [22].

A very important aspect of neonatal intestinal colonization is the method of feeding [3,23]. Oligosaccharides contained in mother's milk constitute about 200 different sugar structures, which can protect the new-born from necrotizing enterocolitis, candidiasis, and other immunological diseases [24]. Bacteria found in breast or all milk are mainly: Staphylococcus, Streptococcus, Lactobacillus, and Bifidobacterium, as well as Pseuduomonas, Edwardsiella, Pantoea, Treponema, Campylobacteri, and others. Milk is the main source of bacteria for infants. A child who drink $800 \mathrm{~mL}$ of this liquid ingests about $10^{5}-10^{7}$ bacteria per day [25]. The change from breast milk to cow's milk causes a significant decrease in the content of $C$. difficile in infant stools. An increase in the amount of Bacteroidetes spp., Blautia spp., Parabacteroidetes spp., Coprococcus spp. Parabacteroidetes spp., Coprococcus spp., Ruminococcus spp., and Oscillospira spp. is also observed. Additionally, there is a reduction in the numbers of Bifidobacterium spp., Lactobacillus spp., Escherichia spp., and Clostridium spp. [26].

Specific diets, i.e. Mediterranean, vegetarian, vegan, and western, affect the composition of the microbiome [27].

According to De Fillippis et al., a vegan or vegetarian diet with a high degree of compliance with its principles promotes the formation of a beneficial microbial profile, contributing to the increased production of SCFA and higher numbers of Provotella bacteria [28, 29]. According to Zimmer et al., a vegetarian diet contributes to reduction in the number of bacterial strains of the following genera: Bacteroides, Bifidobacterium, E. coli, and Enterobacteriaceae, while it does not affect the number of strains of, i.e.: E. coli biovars, Klebsiella, Enterobacter, Enterococcus, Lactobacillus, Citrobacter, Clostridium [30]. The results obtained by Matijašić et al. indicate that following a vegetarian diet contributes to a higher content of Bacteroides-Prevotella, Bacteroides thetaiotaomicron, Clostridium clostridioforme, and Faecalibacterium prausnitzii, with a lower content of Clostridium XIVa compared to those following an omnivorous diet [31]. działania chorobotwórczego [14, 16]. Mikrobiota spełnia funkcje ochronne (tworzy barierę ochronną przed drobnoustrojami chorobotwórczymi), syntetyzuje witaminy K i z grupy B, krótkołańcuchowe kwasy tłuszczowe (SCFA), trawi niestrawione przez człowieka składniki pokarmowe, przez co pozyskuje energię, przyczynia się do sprawnego funkcjonowania motoryki jelit, rozkłada toksyny i karcynogeny, metabolizuje leki. Upośledzenie tych funkcji może skutkować problemami w utrzymaniu homeostazy organizmu $[17,18,19]$.

\section{CZYNNIKI ŻYWIENIOWE MODULUJĄCE SKŁAD MIKROBIOTY}

Na kształtowanie się mikrobioty człowieka wpływają takie czynniki, jak: wiek ciążowy, rodzaj porodu, sposób karmienia i przyjmowane leki w okresie noworodkowym i niemowlęcym, a także późnej, sposób żywienia na różnych etapach życia, wiek [20, 21]. Analiza mikrobiomu w zależności od cech gospodarza może przyczynić się do poznania wszystkich czynników, które oddziałują na jego stan i reakcji, które przyczyniają się do zachowania homeostazy [22].

Bardzo istotnym aspektem kolonizacji jelit noworodka jest sposób karmienia [3, 23]. Oligosacharydy zawarte w mleku matki stanowią około 200 różnych struktur cukrowych, które mogą chronić noworodka przed martwiczym zapaleniem jelit, kandydozami oraz innymi chorobami immunologicznymi [24]. Do bakterii występujących w mleku należą przede wszystkim: Staphylococcus, Streptococcus, Lactobacillus, Bifidobacterium, Pseuduomonas, Edwardsiella, Pantoea, Treponema, Campylobacteri. Mleko stanowi główne źródło bakterii dla niemowląt. Dziecko, które spożywa $800 \mathrm{~mL}$ tego płynu, dostarcza do organizmu ok. $10^{5}-10^{7}$ bakterii dziennie [25]. Zmiana mleka kobiecego na krowie prowadzi do znacznego spadku zawartości C.difficile w kale niemowląt. Obserwuje się również zmniejszenie liczebności Bifidobacterium spp., Lactobacillus spp., Escherichia spp. oraz Clostridium spp, a następuje wzrost liczebności Bacteroidetes spp., Blautia spp., Parabacteroidetes spp., Coprococcus spp. Parabacteroidetes spp., Coprococcus spp., Ruminococcus spp. i Oscillospira spp. [26].

Stosowanie diet tj. śródziemnomorskiej, wegetariańskiej, wegańskiej i zachodniej wpływa na skład mikrobiomu [27].

Według De Fillippis i wsp., diety wegańska i wegetariańska z wysokim stopniem zgodności z ich zasadami sprzyjają kształtowaniu się korzystnego profilu mikrobiomu jelit, przyczyniając się do zwiększonej produkcji SCFA i większej liczebności bakterii z rodzaju Provotella $[28,29]$. Według Zimmer i wsp. dieta wegetariańska przyczynia się do obniżenia liczebności szczepów bakterii z rodzaju: Bacteroides, Bifidobacterium, E. coli, Enterobacteriacea, podczas gdy nie ma wpływu na liczebność szczepów tj.: E. coli biovars, Klebsiella, Enterobacter, Enterococcus, Lactobacillus, Citrobacter, Clostridium [30]. Wyniki uzyskane przez Matijašić i wsp. wskazują na to, że stosowanie diety wegetariańskiej przyczynia się do wyższej zawartości szczepów Bacteroides-Prevotella, Bacteroides thetaiotaomicron, 
In people following a Mediterranean diet, apart from changes in the composition of the microbiome, a lower concentration of acetate, which is part of the SCFA analysed in the faeces, and a higher rate of defecation are observed [32]. According to Gutiérrez-Díaz et al., people who follow the principles of a Mediterranean diet have higher concentrations of phenylacetic and phenylpropic acids, which are the main metabolites excreted in the faeces, and their microbiota are characterized by a higher abundance of Clostridium XVIa and Feacelibacterium prusnitzii strains. It was also observed abstinence from alcohol promotes a favourable phenolic profile of faeces [33]. A study comparing the effects of consumption of saturated and polyunsaturated fatty acids (PUFAs) from fish shows that they cause significant differences in the composition of the microbiome. A diet rich in fish fat prevents negative changes in the composition of the microbiome and lowers the concentration of parameters that indicate inflammation that accompanies obesity [34].

The intestinal microbiome of people consuming a Western diet is strongly dominated by strains of Firmicutes type bacteria. In a study conducted by De Filippo et al., which compared the intestinal microbiota of children from Burkina Faso and European children, it was observed that the microbiota of children who consumed a Western diet were characterized by the predominance of strains of Bacteroides and higher gram positive bacteria of the Firmicutes type. The microbiome of African children was more diverse, dominated by bacteria of the genus Provatella and Enterococcus, and was characterized by a lower content of pathogenic strains from the Enterobacteriaceae family [35]. It is observed that a diet rich in fat and protein of animal origin contributes to the change in the composition of the microbiome [34].

\section{FOLATES - METABOLISM, DEMAND, AND SOURCES}

Folates are found mainly in the form of polyglutamylates, whereas folic acid is an oxidized form of monoglutamate [36]. Folic acid is not active as a coenzyme and has to undergo several metabolic steps inside the cell to be converted into the active form, 5-methyl-THF (tetrahydropholate) [37]. The polyglutamate form must be hydrolysed to folate monoglutamate prior to absorption. This process is facilitated by glutamate carboxypeptidase II, which is found mainly within the brush border of the proximal jejunum. Folate monoglutamate is transported through the apical enterocyte membrane [36]. In enterocytes, a two-step reduction reaction occurs under the influence of dihydrofolate reductase, converting folate monoglutamate to dihydrofolate and then to tetrahydrofolate, which in later metabolism is methylated to 5-methyltetrahydropholate (5-MTHF) [36, 37]. The 5-MTHF form is transported to the blood. Folates in the form of 5-MTHF circulate in the blood from where they are taken up by cells [36].
Clostridium clostridioforme i Faecalibacterium prausnitzii przy niższej zawartości Clostridium XIVa w stosunku do stosowania diety wszystkożernej [31].

U osób stosujących dietę śródziemnomorską, oprócz zmian w składzie mikrobiomu, obserwuje się niższe stężenie octanu, który wchodzi w skład SCFA analizowanych w kale, a także wyższą częstość defekacji [32]. Według Gutiérrez-Díaz i wsp. osoby, które ściśle przestrzegają zasad tego typu diety, posiadają wyższe stężenie kwasów fenylooctowych i fenylopropinowych, które są głównymi metabolitami wydalanymi z kałem oraz cechują się wyższą obfitością szczepów Clostridium XVIa i Feacelibacterium prusnitzii. Zaobserwowano również, że brak spożycia alkoholu sprzyja korzystnemu profilowi fenolowemu kału [33]. Badanie porównujące wpływ spożycia kwasów tłuszczowych nasyconych i wielonienasyconych (WNKT) pochodzących z ryb wykazuje znaczne różnice w składzie mikrobiomu. Dieta bogata w tłuszcze ryb zapobiega negatywnym zmianom w składzie mikrobiomu i obniżeniu stężenia parametrów świadczących o stanach zapalnych, które towarzyszą otyłości [34].

Mikrobiom jelit osób odżywiających się dietą zachodnią jest silnie zdominowany przez szczepy należące do bakterii typu Firmicutes. W badaniu przeprowadzonym przez De Filippo i wsp., w którym porównano mikrobiom jelit dzieci z Burkina Faso i europejskich, zaobserwowano, że mikrobim dzieci odżywiających się dietą zachodnią charakteryzował się przewagą szczepów bakterii z rodzaju Bacteroides i większą liczebnością gam dodatnich bakterii typu Firmicutes. Mikrobiom dzieci z Afryki był bardziej zróżnicowany i zdominowany przez bakterie rodzaju Provatella i enterokoki oraz cechował się niższą zawartością patogennych szczepów z rodziny Enterobacteriacea [35]. Obserwuje się, że dieta bogata w tłuszcz i białko pochodzenia zwierzęcego przyczynia się do zmiany składu mikrobiomu [34].

\section{FOLIANY - METABOLIZM, ZAPOTRZEBOWANIE I ŹRÓDŁA}

Foliany występują głównie w postaci poliglutaminianów, natomiast kwas foliowy stanowi utlenioną formę monoglutamianu [36]. Kwas foliowy nie jest aktywny jako koenzym i musi przejść kilka etapów metabolicznych wewnątrz komórki, aż do przekształcenia w aktywną postać 5-metylo-THF (tetrahydrofolian) [37]. Forma poliglutaminianu musi zostać zhydrolizowana do monoglutaminianu folianu przed absorpcją. Proces ten przeprowadzany jest przez karboksypeptydazę glutaminianową II, która występuje głównie w obrębie rąbka szczoteczkowego bliższej części jelita czczego. Monoglutaminian folianu jest transportowany przez szczytową błonę enterocytu [36]. W enterocy tach następuje dwustopniowa reakcja redukcji pod wpływem reduktazy dihydrofolianowej do dihydrofolianu, a następnie do tetrahydrofolianu, który w dalszych etapach metabolizmu jest metylowany do 5-metylotetrahydrofolianu (5-MTHF) [36, 37]. Postać 5-MTHF zostaje przetransportowana do krwi. Foliany w formie 5-MTHF krążą we krwi, skąd są pobierane przez komórki [36]. Naturalnie 
Naturally, folates are derivatives differentiated by the number of glutamic acid residues and the degree of oxidation of the pteridine ring. Folates are contained in food of plant and animal origin, with majority found in plant products [38]. The richest sources are legumes, followed by dark green vegetables and spices [39]. Apart from food, humans can also obtain folate from the microbiome, which is responsible for its synthesis [40]. A healthy adult needs $400 \mu \mathrm{g}$ folates per day. Demand is increased during pregnancy $(600 \mu \mathrm{g} /$ day $)$ and lactation (500 $\mu \mathrm{g} /$ day) [41].

\section{BIOAVAILABILITY}

The bioavailability of folic acid - the amount and speed with which this nutrient is absorbed in the digestive system depends on many factors [42]: the form of folates, type of products (natural, supplements) and how they are consumed (raw, cooked), drug intake, intake of alcohol, and smoking. Absorbance of folates from plant products is limited due to the presence of a conjugate inhibitor in vegetables and oranges. In products of animal origin (except for the liver), there are on average 2-2.5 times less folates, however, they are characterized by a higher bioavailability [43]. The structure of folates is a factor in determining their bioavailability, because monoglutamylfolates (e.g. contained in the liver) are readily absorbed, whereas polyglutamine conjugates (contained in vegetables) require an earlier reduction reaction [38]. By far the most highly bioavailable form of folic acid is (the degree of absorption on an empty stomach is determined at $100 \%$ ) that taken in the form of supplements or contained in enhanced products [42]. It has been estimated that $85 \%$ of folates from dietary supplements and 50\% from food are bioavailable [39]. Some medicines that are folic acid antagonists lower the concentration of folic acid in the blood as a result of inhibition of dihydrofolate reductase. These include painkillers (aspirin, ibuprofen), antiepileptic drugs (cortisone, sulphamides, phenyladea), methotrexate used to treat patients with rheumatoid arthritis in whom NSAIDs (non-steroidal anti-inflammatory drugs) are not effective, antibacterial drugs (trimethoprim), and quinolones (diaminobenzyl pyrimidine) [44].

\section{THE MICROBIOTA AS A SOURCE OF FOLATES}

For growth, bacteria require the raw materials necessary for the synthesis of molecules that form organelles (mitochondria, nuclear membrane, Golgi apparatus, cytoplasmic membrane, and endoplasmic reticulum with numerous ribosomes) and for energy production. Minimum growth requirements for bacteria include sources of carbon, nitrogen, energy, water, and ions. The intestinal microbiota has been recognized as a source of certain vitamins [45]. It has been shown that folates are synthesized by bacteria and absorbed by two mechanisms: active absorption, mediated by various types of transporters with distinct specificities for different forms of folate, and passive foliany stanowią pochodne zróżnicowane między sobą liczbą reszt kwasu glutaminowego oraz stopniem utlenienia pierścienia pterydyny. Foliany zawarte są w żywności pochodzenia roślinnego i zwierzęcego, przy czym w przeważającej ilości znajdują się w produktach roślinnych [38]. Najbogatszym źródłem są rośliny strączkowe, a następnie ciemnozielone warzywa i przyprawy [39]. Poza pożywieniem człowiek czerpie foliany również z mikrobiomu, który odpowiada za jego syntezę [40]. Zdrowa osoba dorosła potrzebuje $400 \mu \mathrm{g}$ folianów na dobę. Zapotrzebowanie ulega zwiększeniu w trakcie ciąży (600 $\mu \mathrm{g} /$ dobę) i okresie laktacji (500 $\mu \mathrm{g} / \mathrm{dobę})$ [41].

\section{BIODOSTĘPNOŚĆ}

Ilość i szybkość, z jaką kwas foliowy jest wchłaniany w układzie pokarmowym, zależą od wielu czynników [42]: postaci folianów, rodzaju produktów (naturalne, suplementy) i sposobu ich spożywania (surowe, gotowane), przyjmowanych leków, spożycia alkoholu i palenia papierosów. Przyswajalność z produktów roślinnych jest ograniczona z uwagi na obecność inhibitora koniugazy w warzywach i pomarańczach. W produktach pochodzenia zwierzęcego (z wyjątkiem wątroby) jest średnio 2-2,5 razy mniej folianów, jednak charakteryzują się wyższą biodostępnością [43]. Budowa folianów jest jednym z czynników determinujących ich biodostępność, ponieważ monoglutamylofoliany (np. zawarte w wątrobie) są gotowe do wchłonięcia, natomiast koniugaty poliglutaminowe (zawarte w warzywach) wymagają wcześniejszej reakcji redukcji [38]. Zdecydowanie największą biodostępnością cechuje się syntetyczny kwas foliowy (stopień przyswajalności na czczo określa się na 100\%), przyjmowany w postaci suplementów bądź zawarty w fotyfikowanych produktach [42]. Przyjęto, że 85\% folianów z suplementów diety i 50\% z żywności jest biodostępnych [39]. Niektóre leki będące antagonistami kwasu foliowego obniżają jego stężenie we krwi w wyniku hamowania reduktazy dihydrofolianowej. Są to m.in. leki przeciwbólowe (aspiryna, ibuprofen), przeciwpadaczkowe (kortyzon, sulfamidy, fenytiona), metotreksat, stosowany u chorych z reumatoidalnym zapaleniem stawów, u których NLPZ (niesteroidowe leki przeciwzapalne) nie są skuteczne, leki przeciwbakteryjne (trimetroprim), chinolony (diaminobenzylopirymidyna) [44].

\section{MIKROBIOTA JAKO ŹRÓD ŁO FOLIANÓW}

Bakterie do wzrostu wymagają surowców koniecznych do syntezy cząsteczek, tworzących organella (mitochondria, błona jądrowa, aparat Golgiego, błona cytoplazmatyczna oraz retikulum endoplazmatyczne z licznymi rybosomami), oraz wytwarzania energii. Minimalne wymagania wzrostowe bakterii obejmują źródła węgla, azotu, energii, wody oraz jonów. Pierwiastki konieczne do syntezy białek, tłuszczów i węglowodanów to: C, 0 , H, N, S, P. Mikrobiom jelit uznany został za źródło niektórych witamin [45]. Udowodniono, że foliany są syntezowane przez bakterie i wchłaniane poprzez 2 mechanizmy: absorbcję, w której 
absorption in the presence of folate receptors. Folates absorbed in this way can then be used by the host $[8,45,46]$. There is a lack of information on the amount of folic acid produced inside and outside the cell, and the bioavailability of the folic acid produced in this way.

Several attempts have been made to characterize the metabolic pathways leading to the production of folic acid by Bifidobacteria in vitro [40]. Results obtained in recent years have shown that all strains of human Bifidobacteria (HRB), except for B. gallicum and B. biavatii, have a set of genes that are involved in folate biosynthesis $[6,7,8]$. For many microorganisms, p-aminobenzoic acid is an indispensable substrate. Together with adenosine triphosphate (ATP), it condenses with pteridine and glutamic acid to form dihydrofolate acid, which is then converted to folic acid. Sugahara et al. determined the potential of 44 bacterial strains including 12 species and 7 subspecies of Bifidobacteria for folate synthesis when cultured in MRS medium (de Man, Rogosa and Sharpe) containing cysteine. Higher in vitro potential for folic acid synthesis has been observed in HRB strains than in non-HRB. Non-HRB strains that have the ability to synthesize folates include B. thermophilum and B. longum ssp. [7]. Wild-type lactic acid bacteria do not have the ability to synthesize folate, but they require it for growth. The exception is Lactobacillus plantarum, which, in the presence of para-aminobenzoic acid, has the ability to synthesize folates [45]. In a study conducted by Pompei et al., in which 76 strains of Bifidobacterium were isolated, it was observed that most strains need folic acid for growth. All isolated Bifidobacterium strains grew well in a synthetic medium containing $1 \mu \mathrm{g} / \mathrm{L}$ of folic acid. It was observed that lack of folates led to the death of 59 strains. The remaining 17 strains were characterized by a further growth. It was shown that 6 strains of Bifidobacterium - B. animalis F 200, B. bifidum 106, B. centenulatum DSMZ 16992, B. dentium MB 117, B. infantis 15697 (American Type Culture Collection ATCC), and B. longum MB 214 - out of 17 which grew without folates, produced much higher amounts of this vitamin (between 41 and $82 \mathrm{ng} / \mathrm{mL}$ ). It was observed that B. adolescentis (MB 114, MB 115, MB 227, MB 227, MB 239) and B. pseudocentenulatum (MB 116 and MB 237) strains were characterized by the highest biosynthesis of folates ( $>40 \mathrm{ng} / \mathrm{mL}$ ) [46]. Similar conclusions were reached by Strozzi and Mogna. Subjects were divided into three groups and were supplemented with one of three probiotic strains: Bifidobacterium adolscentis Deutsche Sammlung von Mikroorganismen nd Zellkulturen (DSM) 18350 (group A), Bifidobacterium adolscentis DSM 18352 (group B), or Bifidobacterium pseudocatenulatum DSM 18353 (group C). The study showed a significant increase in folate concentrations in human faeces, in particular after supplementation with B. pseudocatenulatum $(\mathrm{p}<0,05)$ [8]. In turn, in a study by Pompei et al. conducted on Wistar rats, supplementation with the selected bacteria strains and/or probiotics was performed. The first group (PRO) received a mixture of Bifidobacterium (B. adolescentis MB 227, B. adolescentis MB 239, and B. pseudocatenulatum MB 116) strains, while the PRE group received oligofructose, and the SYM group received pośredniczą różnego rodzaju transportery o wyraźnej swoistości dla różnych form folianów, oraz absorbcję bierną w obecności receptorów folianów. Wchłonięte w ten sposób foliany mogą być następnie użytkowane przez gospodarza [8, 45, 46]. Brakuje informacji na temat ilości kwasu foliowego wytwarzanego wewnątrz- i zewnątrzkomórkowo oraz jego biodostępności.

Podjęto kilka prób scharakteryzowania szlaków metabolicznych prowadzących do wytworzenia kwasu foliowego przez Bifidobacterie in vitro [40]. Wyniki badań przeprowadzonych w ostatnich latach wykazały, że wszystkie szczepy ludzkich Bifidobacterii (Human-residential Bifidobacteria - HRB) z wyjątkiem m.in. B. gallicum i B. biavatii posiadają zestawy genów, które biorą udział w biosyntezie folianów $[6,7,8]$. Dla wielu mikroorganizmów kwas p-aminobenzoesowy jest niezbędnym substratem. Przy udziale adenozynotrifosforanu (ATP) kondensuje on z pterydyną i kwasem glutaminowym do kwasu dihydrofolianowego, który następnie jest przekształcany do kwasu foliowego. W badaniu Sugahara i wsp. określono potencjał 44 szczepów bakterii, w tym 12 gatunków i 7 podgatunków Bifidobacterii do syntezy folianów podczas hodowli w pożywce MRS (de Man, Rogosa i Sharpe) zawierającej cysteinę. U szczepów HRB zaobserwowano wyższy potencjał in vitro do syntezy kwasu foliowego niż u nie-HRB. Do szczepów nie-HRB, które posiadają zdolność syntezy folianów należą $B$. thermophilum i B. longum ssp. [7]. Bakterie kwasu mlekowego typu dzikiego nie wykazują zdolności do syntezy folianów, wymagają ich do wzrostu. Wyjątek stanowi Lactobacillus plantarum, który w obecności kwasu para-aminobenzoesowego posiada zdolność do syntezy folianów [45]. W badaniu przeprowadzonym przez Pompei i wsp., w którym wyizolowano 76 szczepów Bifidobacterium zaobserwowano, że większość szczepów do swojego wzrostu potrzebuje kwasu foliowego. Wszystkie wyizolowane szczepy Bifidobacterium dobrze rosły w syntetycznej pożywce zawierającej $1 \mu \mathrm{g} / \mathrm{L}$ kwasu foliowego. Zaobserwowano, że brak folianów doprowadził do śmierci 59 szczepów. Pozostałe 17 charakteryzowało się dalszym wzrostem. Wykazano, że 6 szczepów Bifidobacterium - B. animalis F 200, B. bifidum 106, B. centenulatum DSMZ 16992, B. dentium MB 117, B. infantis (Amercian Type Culture Collection - ATCC) 15697 i B. longum MB 214 - spośród 17, które rosły bez folianów, wytwarzało znacznie wyższe ilości tej witaminy (między 41 a $82 \mathrm{ng} / \mathrm{mL}$ ). Zaobserwowano, że szczepy B. adolescentis (MB 114, MB 115, MB 227, MB 227, MB 239) oraz B. pseudocentenulatum (MB 116 i MB 237) charakteryzowały się najwyższą biosytezą folianów (>40 ng/mL) [46]. Do podobnych wniosków doszli Strozzi i Mogna w badaniu, w którym uczestników podzielono na 3 grupy. Osoby te były suplementowane jednym z trzech probiotycznych szczepów: Bifidobacterium adolscentis Deutsche Sammlung von Mikroorganismen nd Zellkulturen (DSM) 18350 (grupa A), Bifidobacterium adolscentis DSM 18352 (grupa B), bądź Bifidobacterium pseudocatenulatum DSM 18353 (grupa C). W badaniu zaobserwowano znaczny wzrost stężenia folianów w ludzkim kale, w szczególności po suplementacji B. pseudocatenulatum $(\mathrm{p}<0,05)$ [8]. Z kolei w badaniu Pompei i wsp., przeprowadzonym na szczurach rasy Wistar, poszczególne grupy suplementowano wybranymi szczepami bakterii i/lub prebiotykami. Grupa pierwsza (PRO) otrzymywała 
the Bifidobacterium strains. Each group was supplemented for 14 days, which contributed to a statistically significant increase $(\mathrm{p}<0,05)$ in folate concentrations in the plasma of all rats. The highest concentration of folic acid was observed in the SYM group (16.4 $\pm 3.7 \mathrm{nmo} / \mathrm{L})$, while a lower concentration was observed in the PRO group $(9.1 \pm 0.3 \mathrm{nmol} / \mathrm{L})$, and with the lowest concentration observed in the PRE group (5.3 $\pm 1.4 \mathrm{nmol} / \mathrm{l})$ [47].

Metformin is the first-line drug that is used to improve glycaemia in people with type II diabetes. The drug is used as a monotherapy in combination with lifestyle modification (increase in physical activity by $30-45 \mathrm{~min} / \mathrm{d}$ and body weight reduction). The drug has three principles of antidiabetic action. Under the influence of metformin, glucose production in the liver is reduced by the inhibition of gluconeogenesis and glycogenolysis, as well as a delay in the absorption of glucose in the intestines. Sensitivity to insulin increases in the muscles, increasing peripheral glucose uptake and consumption. Under the influence of metformin, postprandial fasting glycemia is reduced by $60-70 \mathrm{mg} / \mathrm{dL}$ and HbA1c (glycated haemoglobin) by 1-2\%. The reference value of glycemia on an empty stomach in a blood sample taken $8-14 \mathrm{~h}$ after the last meal is $<100 \mathrm{mg} / \mathrm{dL}$, and the abnormal value is $100-125 \mathrm{mg} / \mathrm{dL}$. Apart from the effect of metformin on the level of glycaemia, this drug also has a beneficial effect on lipid metabolism $[48,49]$. Metformin affects the synthesis of folate by the microbiome. It was observed that the drug increases the viability of Coenorhabditis elegans and reduces the synthesis of folates by the microbiome [50,51,52], which translates into a decrease in the concentration of folates in the blood $[53,54]$. Folates together with metformin reduce insulin resistance [55]. According to Palomba et al., supplementation with folic acid during metformin treatment enhances blood glucose reduction $[55,56]$. Another group of drugs affecting the ability of the microbiota to synthesize folic acid are sulphonamides. They are structural analogues of p-aminobenzoic acid (PABA) and therefore inhibit the synthesis of dihydrofolate (DHF). Sulphonamides may enter the DHF synthesis reaction instead of PABA and compete for active enzyme. As a result, non-functional folic acid analogs prevent further growth of bacterial cells. The inhibitory effect of sulphonamides can be counteracted by excess PABA in the environment [57].

\section{THE INFLUENCE OF FOLATES ON HUMAN HEALTH}

A deficiency of folates in the diet contributes to many health problems [44]. The most important pathological processes associated with folic acid deficiency include: megaloblastic anaemia, neural tube formation defects in the foetus, nervous system disorders, and atherosclerosis and related cardiovascular dysfunctions [38]. Folate deficiencies may result from insufficient dietary supply, increased demand (pregnancy, infection, haemolytic anaemia), disturbances in intestinal absorption, or taking of oral contraceptives $[57,58]$. mieszaninę szczepów Bifidobacterium (B. adolescentis MB 227, B. adolescentis MB 239, and B. pseudocatenulatum MB 116), druga (PRE) otrzymywała oligofruktozę, a trzecia (SYM) oligofruktozę i szczepy Bifidobacterium. Każda z grup była suplementowana przez 14 dni, co przyczyniło się do statystycznie istotnego wzrostu $(\mathrm{p}<0,05)$ stężenia folianów w osoczu krwi wszystkich szczurów. Najwyższe stężenie kwasu foliowego zaobserwowano w grupie SYM $(16,4 \pm 3,7 \mathrm{nmol} / \mathrm{L})$, niższe w grupie PRO (9,1 $\pm 0,3 \mathrm{nmol} / \mathrm{L})$, a najniższe w grupie PRE (5,3 $\pm 1,4 \mathrm{nmol} / \mathrm{L})$ [46].

Metformina jest lekiem pierwszego rzutu, który przyjmują osoby chore na cukrzycę typu II w celu poprawy glikemii. Lek jest stosowany w monoterapii w połączeniu z modyfikacją stylu życia (zwiększenie aktywności fizycznej o 30-45 min/d oraz redukcja masy ciała). Ma on 3 zasady działania przeciwcukrzycowego. Pod wpływem metforminy dochodzi do zmniejszenia wytwarzania glukozy w wątrobie poprzez hamowanie glukoneogenezy i glikogenozliy, a także opóźnienia absorbcji glukozy w jelitach. W mięśniach następuje zwiększenie wrażliwości na insulinę, wzmagające obwodowy wychwyt glukozy i jej zużycie. Pod wpływem działania metforminy dochodzi do obniżenia poposiłkowej glikemii na czczo o 60-70 mg/dL i HbA1c (hemoglobiny glikowanej) o 1-2\%. Wartość referencyjna glikemii na czczo w próbce krwi pobranej 8-14 godz. od ostatniego posiłku wynosi <100 mg/dL, a wartość nieprawidłowa to $100-125 \mathrm{mg} / \mathrm{dL}$. Niezależnie od wpływu metforminy na poziom glikemii, metformina wywiera również korzystny wpływ na matabolizm lipidów [47, 48]. Jest ona czynnikiem, który oddziałuje na syntezę folianów przez mikrobiom. Zaobserwowano, że lek zwiększa żywotność Coenorhabditis elegans i zmniejsza syntezę folianów przez mikrobiom [49, 50, 51], co przekłada się na obniżenie stężenia folianów we krwi $[52,53]$. Foliany wraz z metforminą zmniejszają insulinooporność [54]. Według Palomba i wsp. suplementacja kwasem foliowym w trakcie leczenia metforminą przyczynia się do zwiększenia obniżenia się poziomu glikemii we krwi [55, 56]. Kolejną grupą leków wpływającą na zdolność mikrobioty do syntezy kwasu foliowego są sulfonamidy. Są one strukturalnymi analogami kwasu p-aminobenzoesowego (PABA) i hamują syntezę dihydrofolianu (DHF). Sulfonamidy mogą wchodzić w reakcję syntezy DHF zamiast PABA i konkurować o aktywny ośrodek enzymu. W rezultacie niefunkcjonalne analogi kwasu foliowego zapobiegają dalszemu wzrostowi komórek bakteryjnych. Hamującemu działaniu sulfonamidów można przeciwdziałać nadmiarem PABA w środowisku [56].

\section{WPŁYW FOLIANÓW NA ZDROWIE CZŁOWIEKA}

Niedobór folianów w diecie przyczynia się do wielu problemów zdrowotnych [44]. Do najważniejszych procesów chorobowych organizmu związanych z niedoborem kwasu foliowego należą: powstawanie wad cewy nerwowej u płodu, zaburzenia układu nerwowego, niedokrwistość megaloblastyczna, miażdżyca i związane z nią dysfunkcje układu sercowo-naczyniowego [38]. Do niedoborów może dojść na skutek: niedostatecznej podaży w diecie, zaburzenia wchłaniania w jelitach, 


\section{SUMMARY}

Available literature on the potential of the microbiota for folate synthesis indicates primarily HRB strains as contributing to the increase in folate content and, to a small extent, indicates factors that may affect the microbiome's potential for folate synthesis. In the available literature, metformin is the only indicated factor that can influence the microbiota's potential for folate synthesis. In order to thoroughly understand the ability of the microbiota to synthesize folic acid, it is necessary to carry out further studies that will include people who are exposed to various factors that may affect their health, such as: poor dietary habits, smoking, low physical activity, dietdependent diseases, or taking medicines. doustnej antykoncepcji, zwiększonego zapotrzebowania (ciąża, zakażenia, niedokrwistość hemolityczna) [57,58].

\section{PODSUMOWANIE}

Dostępna literatura dotycząca potencjału mikrobioty do syntezy folianów przede wszystkim uznaje HRB jako szczepy przyczyniające się do zwiększenia ilości folianów i w niewielkim stopniu wskazuje na czynniki, które mogą wpływać na potencjał mikrobiomu do syntezy folianów - metforminę. W celu dokładnego poznania zdolności mikrobioty do syntezy kwasu foliowego potrzebne jest przeprowadzenie badań, w których zostaną uwzględnione osoby w różnym stopniu narażone na występowanie czynników, mogących wpływać na stan zdrowia, takich jak: nieprawidłowy sposób żywienia, palenie papierosów, niska aktywność fizyczna, występowanie chorób o podłożu dietozależnym czy przyjmowanie leków.

\section{REFERENCES / PIŚMIENNICTWO}

1. Karwoska Z, Majchrzak K. Wpływ błonnika na zróżnicowanie mikroflory jelitowej (mikrobiota jelit). Bromat Chem Toksykol 2015;48(4): 701-9.

2. Turnbaugh PJ, Ley RE, Hamady M, Fraser-Liggett C, Knight R, Gordon JI. The human microbiome project: exploring the microbial part of ourselves in a changing world. Nature 2007;449(7164):804-10.

3. Gałęcka M, Bartnicka A, Szewc M, Mazela J. Kształtowanie się mikrobioty jelitowej u niemowląt warunkiem zachowania zdrowia. Stand Med, Pediatr 2016;13:359-67.

4. Łoś-Rycharska E, Czerwionka-Szaflarska M. Inhibitory pompy protonowej a mikrobiom przewodu pokarmowego. Pediatria Pol 2017;1-4. doi:10.1016/j.pepo.2016.12.011.

5. Graf D, Di Cagano R, Fåk F, Flint HJ, Nyman M, Saarela M, et al. Contribution of diet to the composition of the human gut microbiota. Microb Ecol Health Dis 2015;26:26164.

6. D'Aimmo MR, Mattarelli P, Biavati B, Carlsson NG, Andlid T. The potential of bifidobacteria as a source of natural folate. J Appl Microbiol 2012;112(5):975-84.

7. Sugahara H, Odamaki T, Hashikura N, Abe F, Xiao JZ. Diffences in folate production by bifidobacteria of different orgins. Biosci Microbiota Food Health 2015;34(4):87-93.

8. Strozzi GP, Mogna L. Quantification of folic acid in human feces after administration of Bifidobacterium probiotic strains. J Clin Gastroenterol 2008;42(Suppl 3 Pt 2):S179-84.

9. Human Microbiome Project Consortium. Structure, function and diversity of the healthy human microbiome. Nature 2012;486:207-14.

10. Giliński Z, Grzegorczyk K. Probiotyki jako immunostymulatory w weterynarii i medycynie. Życie Weterynaryjne 2017;92(12):871-5.

11. Nowak A, Libudzisz Z. The intestinal microbiota of humans. Stand Med, Pediatr 2008;5:372-9.

12. Stachowicz N, Kiersztan A. Rola mikroflory w patogenezie otyłości i cukrzycy. Post Hig 2013;67:288-303.

13. Górska S, Jarząb A, Gamian A. Bakterie probiotyczne w przewodzie pokarmowym człowieka jako czynnik stymulujący układ odpornościowy. Post Hig 2009;63:653-67.

14. Dziewiatowska J, Janczy A, Steinka I, Pieszko M, Małgorzewicz S. Związek pomięd zy mikroflorą a otyłością. Forum Zaburzeń Metabolicznych 2014;5(1):20-5.

15. Krakowiak O, Nowak R. Mikroflora przewodu pokarmowego człowieka znaczenie, rozwój, mody fikacje. Post Fitoter 2015;3:193-9.

16. DiBaise JK, Zhang H, Crowell MD, Krajmalnik-Brown R, Decker GA, Rittmann BE. Gut microbiota and its possible relationship with obesity. Mayo Clin Proc 2008;83(4):460-9.
17. Arobleya S, Watkins C, Stanton C, Ross RP. Gut Bifidobacteria Populations in Human Health and Aging. Front Microbiol 2016;7:1204.

18. Cardinelli CS, Sala PC, Alves CC, Torrinhas RS, Waitzberg DL. Influence of intestinal microbiota on body weight gain: a narrative review of the literature. Obes Surg 2015;25(2):346-53.

19. Tokarz-Deptuła B, Śliwa-Dominiak J, Adamiak M, Bąk K, Deptuła W. Bakterie komensalne a odporność układu pokarmowego, oddechowego i moczowo-płciowego. Post Hig 2016;70:599-609.

20. Bartnicka A, Gałęcka M, Mazela J. Wpływ czynników prenatalnych i postnatalnych na mikrobiote jelitową noworodków. Stand Med, Pediatr 2016;13:165-72.

21. McElroy KG, Chung SY, Regan M. CE: Health and the Human Microbiome: A Primer for Nurses. Am J Nurs 2017;117(7):24-30.

22. Binek M. Mikrobiom człowieka - zdrowie i choroba. Post Mikrob 2012;5(1):27-36.

23. Fiocchi A, Pawankar R, Cuello-Garcia C, Ahn K, Al-Hammadi S, Agarwal A, et al. World Allergy Organization-McMaster University Guidelines for Allergic Disease Prevention (GLAD-P): Probiotics. World Allergy Organ J 2015;8(1):4

24. Moukarzel S, Bode L. Human Milk Oligosaccharides and the Preterm Infant: A Journey in Sickness and in Health. Clin Perinatol 2017;44(1): 193-207.

25. Gomez-Gallego C, Garcia-Mantrana I, Salminen S, Collado MC. The human milk microbiome and factors influencing its composition and activity. Semin Fetal Neonatal Med 2016;21(6):400-5.

26. Davis MY, Zhang H, Brannan LE, Carman RJ, Boone JH. Rapid change of fecal microbiome and disappearance of Clostridium difficle in a colonized infant after transition from breast milk to cow milk. Microbiome 2016; $4(1): 53$.

27. De Angelis M, Garruti G, Minervini F, Bonfrate L, Portincasa P, Gobbetti M. The food-gut human axis: the effects of diet on gut microbiota and metabolome. Curr Med Chem 2017. doi: 10.2174/0929867324666170428103848.

28. De Filippis F, Pellegrini N, Vannini L, Jeffery IB, La Storia A, Laghi L, et al. High-level adherence to a Mediterranean diet beneficially impacts the gut microbiota and associated metabolome. Gut 2016;65(11):1812-21.

29. Glick-Bauer M, Yeh MC. The health advantage of a vegan diet: exploring the gut microbiota connection. Nutrients 2014;6(11):4822-38.

30. Zimmer J, Lange B, Frick JS, Sauer H, Zimmermann K, Schwiertz A, et al. A vegan or vegetarian diet substantially alters the human colonic faecal microbiota. Eur J Clin Nutr 2012;66(1):53-60.

31. Matijašić BB, Obermajer T, Lipoglavšek L, Grabnar I, Avguštin G, Rogelj I. Association of dietary type with fecal microbiota in vegetarians and omnivores in Slovenia. Eur J Nutr 2014;53(4):1051-64. 
32. Mitsou EK, Kakali A, Antonopoulou S, Mountzouris KC, Yannakoulia M, Panagiotakos DB, et al. Adherence to the Mediterranean diet is associated with the gut microbiota pattern and gastrointestinal characteristics in an adult population. Br J Nutr 2017;117(12):1645-55

33. Gutiérrez-Díaz I, Fernández-Navarro T, Salazar N, Bartolomé B, MorenoArribas MV, de Andres-Galiana EJ, et al. Adherence to a Mediterranean Diet Influences the Fecal Metabolic Profile of Microbial-Derived Phenolics in a Spanish Cohort of Middle-Age and Older People. J Agric Food Chem 2017;65(3):586-95.

34. Martinez KB, Leone V, Chang EB. Western diets, gut dysbiosis, and metabolic diseases: Are they linked? Gut Microbes 2017;8(2):130-42.

35. De Filippo C, Cavalieri D, Di Paola M, Ramazzotti M, Poullet JB, Massart $\mathrm{S}$, et al. Impact of diet in shaping gut microbiota revealed by a comparative study in children from Europe and rural Africa. Proc Natl Acad Sci USA 2010;107(33):14691-6.

36. Ebara S. Nutritional role of folate. Congenit Anom (Kyoto) 2017. doi: 10.1111/cga.12233.

37. Scaglione F, Panzavolta G. Folate, folic acid and 5-methyltetrahydrofolate are not the same thing. Xenobiotica 2014;44(5):480-8.

38. Czeczot H. Kwas foliowy w fizjologii i patologii. Post Hig 2008;62:405-19.

39. Saini RK, Nile SH, Keum YS. Folates: Chemistry, analysis, occurrence, biofortification and bioavailability. Food Res Int 2016;89(Pt 1):1-13.

40. Kopp M, Dürrr K, Steigleder M, Clavel T, Rychlik M. Development of stable isotope dilution assays for the quantitation of intra- and extracellular folate patterns of Bifidobacterium adolescentis. J Chromatogr A 2016;1469:4859. doi: 10.1016/j.chroma.2016.09.048.

41. Jarosz M. Normy żywienia dla populacji polskiej. Warszawa: Wyd. IŻIŻ; 2017.

42. Kapka-Skrzypczak L, Niedźwiecka J, Skrzypczak M, Wojtyła A. Kwas foliowy - skutki niedoboru i zasadność suplementacji. Medycyna Ogólna i Nauki o Zdrowiu 2012;18(1):65-9.

43. Bielecka MM, Cichosz G, Nowak K. Sources of folates in human diet. Folia Pomeranae Univ Technol Stetinensis, Agric Piscaria Zootech 2015;322(36)4:5-28.

44. Okumara K, Tsukamato K. Folate in smokers. Clinica Chimica Acta. 2011; 521-6.

45. Rossi M, Amaretti A, Raimondi S. Folate production by probiotic bacteria. Nutrients 2011;3(1):118-34.

46. Pompei A, Cordisco L, Amaretti A, Zanoni S, Matteuzzi D, Rossi M. Folate production by bifidobacteria as a potential probiotic property. Appl Environ Microbiol 2007;73(1):179-85.
47. Pompei A, Cordisco L, Amaretti A, Zanoni S, Raimondi S, Matteuzzi D, et al. Administration of folate producing bifidobacteria enhances folate status in Wistar rats. J Nutr 2007;137(12):2742-6.

48. Charakterystyka produktu leczniczego. Metformia. http://leki.urpl.gov. pl/files/Metformax_500.pdf (10.10.2018)

49. Czech A, Cypryk K, Czupryniak L, Grzeszczak W, Gumprecht J, Idzior-Waluś B. Zalecenia kliniczne dotyczące postępowania u chorych na cukrzycę 2009. Diabetol Prakt 2009;10(A):1-38.

50. Olgun A. „Metformin-resistant” folic acid producing probiotics or folic acid against metformin's adverse effects like diarrhea. Med Hypotheses 2017;106:33-4

51. Storelli G, Téfit M, Leulier F. Metformin, microbes, and aging. Cell Metab 2013;17(6):809-11.

52. Cabreiro F, Au C, Leung KY, Vergara-Irigaray N, Cochemé HM, Noori T, et al. Metformin retards aging in C. elegans by altering microbial folate and methionine metabolism. Cell Metab 2013;153(1):228-39.

53. Sahin M, Tutuncu NB, Ertugrul D, Tanaci N, Guvener ND. Effects of metformin or rosiglitazone on serum concentrations of homocysteine, folate, and vitamin B12 in patients with type 2 diabetes mellitus. J Diabetes Complicat 2007;21(2):118-23.

54. Wulffelé MG, Kooy A, Lehert P, Bets D, Ogterop JC, Borger van der Burg B, et al. Effects of short-term treatment with metformin on serum concentrations of homocysteine, folate and vitamin B12 in type 2 diabetes mellitus: a randomized, placebo-controlled trial. J Intern Med 2003;254(5): 455-63.

55. Dehkordi EH, Sattari F, Khoshdel A, Kasiri K. Effect of folic acid and metformin on insulin resistance and inflammatory factors of obese children and adolescents. J Res Med Sci 2016;21:71.

56. Palomba S, Falbo A, Giallauria F, Russo T, Tolino A, Zullo F, et al. Effects of metformin with or without supplementation with folate on homocysteine levels and vascular endothelium of women with polycystic ovary syndrome. Diabetes Care 2010;33(2):246-51.

57. Brooks GF, Carroll KC, Butel JS, Morse SA. Medical Microbiology. Lange Basic Science 2007

58. Laskowska-Klita T, Chełchowska M, Ambroszkiewicz J, Gajewska J. Kwas foliowy - rola w metabolizmie komórki. In: Lee H, Ko G, editors. New perspectives regarding the antiviral effect of vitamin A on norovirus using modulation of gut microbiota. Gut Microbes 2017:1-5. 